\title{
HUBUNGAN BIOMASSA EPIFIT DENGAN AKTIVITAS ANTIOKSIDAN LAMUN DI PERAIRAN PULAU PRAMUKA, KEPULAUAN SERIBU, DKI JAKARTA
}

\section{Relationship of Epiphytic Biomass with Antioxidant Activity of Seagrass in Pramuka Island Water, Seribu Islands, DKI Jakarta}

\author{
Mardiyana $^{1 \star}$, Hefni Effendi ${ }^{2}$, Nurjanah ${ }^{3}$ \\ 1Departemen Manajemen Sumberdaya Perairan, Fakultas Perikanan dan Ilmu Kelautan IPB, Jalan Agatis \\ Kampus IPB Darmaga Bogor 16680, Telepon (0251) 8622932 \\ 2Pusat Penelitian Lingkungan Hidup IPB, Jalan Lingkar Akademik Kampus IPB Darmaga Bogor 16680 \\ 3Departemen Teknologi Hasil Perairan, Fakultas Perikanan dan Ilmu Kelautan IPB, Jalan Agatis Kampus \\ IPB Darmaga Bogor 16680 \\ *Korespondensi: mardiyana27juni89@gmail.com \\ Diterima 25 Ferbruari 2014/ Disetujui 02 April 2014
}

\begin{abstract}
Abstrak
Lamun menghasilkan metabolit sekunder yang berperan dalam pertahanan diri dari lingkungan maupun dari serangan organisme lain termasuk organisme penempel/epifit. Penelitian ini bertujuan untuk menganalisis hubungan aktivitas antioksidan dengan biomassa epifit daun lamun Thalassia hemprichii yang hidup di Perairan Pulau Pramuka, Kepulauan Seribu, DKI Jakarta. Metode untuk menganalisis aktivitas antioksidan adalah metode DPPH (1,1-difenil-2-pikrilhidrazil), sedangkan biomassa epifit diperoleh dengan mengerik epifit yang berada di permukaan daun $T$. hemprichii kemudian ditimbang beratnya per satuan luas daun $\left(\mathrm{mg} / \mathrm{cm}^{2}\right)$. Aktivitas antioksidan daun lamun yang digambarkan dengan nilai $\mathrm{IC}_{50}$ berkisar antara 563,88-2039,8 mg/L. Korelasi biomassa epifit dengan $\mathrm{IC}_{50}$ sebesar 0,99 menunjukkan bahwa biomassa epifit mempengaruhi aktivitas antioksidan lamun.
\end{abstract}

Kata kunci: aktivitas antioksidan, epifit, Thalassia hemprichii

\begin{abstract}
Seagrass produces secondary metabolites that play a role in self defense from the environment or from invasion of other organisms including epiphyte organisms. The aim of this study was to analyze the relationship of antioxidant activity with epiphytic biomass Thalassia hemprichii seagrass leaves that lives in the waters of Pramuka Island, Seribu Islands, DKI Jakarta. The antioxidant activity was measured by DPPH (1,1-diphenyl-2 picrylhydrazyl) method while the epiphytic biomass was measured by scraping epiphytes on leaf surfaces and then weighed per unit leaf area $\left(\mathrm{mg} / \mathrm{cm}^{2}\right)$. The antioxidant activity of seagrass illustrated by $\mathrm{IC}_{50}$ values in the range of 563.88 to $2,039.8 \mathrm{mg} / \mathrm{L}$. The correlation between epiphytic biomass with $\mathrm{IC}_{50}$ was 0.99 indicating the biomass of epiphytes influenced on antioxidant activity.
\end{abstract}

Keywords: antioxidant activity, epiphytes, Thalassia hemprichii

\section{PENDAHULUAN}

Reaksi radikal bebas yang berlebihan di dalam tubuh merupakan penyebab penyakit degeneratif misalnya jantung, stroke, dan kanker (Sen et al. 2010). Tubuh memerlukan suatu senyawa untuk menangkal pengaruh radikal bebas ini. Senyawa yang mampu menyelamatkan sel-sel di dalam tubuh manusia dari bahaya radikal bebas adalah senyawa antioksidan (Rohmatussolihat 2009). Antioksidan dapat diperoleh dari sumber alami maupun sintetik. Banyak sumber antioksidan alami yang diperoleh dari laut contohnya rumput laut, spons, dan mikroalga (Hanani et al. 2005; Yoon et al. 2011; Manivanan et al. 2012). Salah satu sumberdaya laut lain yang masih belum banyak dimanfaatkan di Indonesia adalah lamun. 
Lamun adalah tumbuhan berbunga (Angiospermae) yang dapat tumbuh dengan baik pada lingkungan laut dangkal. Lamun senantiasa membentuk hamparan permadani di laut yang dapat terdiri dari satu spesies (monospesifik; banyak terdapat di daerah temperate) atau lebih dari satu spesies (multispesifik; banyak terdapat di daerah tropis) yang selanjutnya disebut padang lamun (Tangke 2010). Padang lamun ini dimanfaatkan oleh organisme laut sebagai tempat mencari makan, berlindung, maupun tempat bereproduksi.

Lamun mampu menghasilkan metabolit sekunder (Choi et al. 2009; Regalado et al. 2012). Metabolit sekunder yang umumnya diproduksi oleh organisme berperan untuk pertahanan diri dari lingkungan maupun dari serangan organisme lain termasuk organisme penempel/epifit, dan mencegah adanya infeksi dari patogen (Murniasih 2003; Marhaeni et al. 2010). Senyawa antioksidan yang dihasilkan oleh lamun Posidonia oceanica berfungsi sebagai senyawa pertahanan diri terhadap stres yang ditimbulkan adanya biota epifit Lophocladia lallemandii (Sureda et al. 2008).

Lamun jenis Thalassia hemprichii merupakan salah satu jenis lamun yang banyak ditemukan di Perairan Pulau Pramuka, tetapi pemanfaatannya secara langsung oleh masyarakat masih jarang dilakukan sehingga perlu upaya eksplorasi terhadap jenis ini agar bisa dimanfaatkan oleh masyarakat. Penelitian ini bertujuan untuk menentukan hubungan aktivitas antioksidan dengan biomassa epifit daun lamun $T$. hemprichii yang hidup di Perairan Pulau Pramuka.

\section{BAHAN DAN METODE}

\section{Bahan dan Alat}

Bahan penelitian terdiri atas sampel daun lamun T. hemprichii dari Perairan Pulau Pramuka, bahan kimia untuk ekstraksi adalah metanol pro-analisis. Bahan lainnya adalah pereaksi Dragendorff, pereaksi Meyer, dan pereaksi Wagner, serbuk magnesium, amil alkohol, alkohol, etanol 70\%, $\mathrm{FeCl}_{3}, \mathrm{HCl} 2 \mathrm{~N}$.
Alat yang digunakan adalah inkubator (Termolina), alat sentrifugasi (Sorvall T-21), evaporator putar (IKA), oven (Yamato), dan spektrofotometer (ELISA reader).

\section{Metode Penelitian}

Pengambilan dan Preparasi Sampel Lamun

Pengambilan sampel daun lamun dilakukan di Pulau Pramuka, pada stasiun yang telah ditentukan. Stasiun penelitian terbagi menjadi tiga (Gambar 1). Stasiun I terletak di bagian barat daya pulau dengan kondisi perairan berarus dan bergelombang serta tergolong daerah subtidal dengan mendapat masukan limbah domestik dari aktivitas wisata dan pemukiman. Stasiun II terletak di bagian utara pulau dengan kondisi perairan berarus dan bergelombang serta tergolong daerah subtidal dengan lingkungan sekitar masih alami dan tidak ada aktivitas manusia. Stasiun III di bagian timur pulau merupakan perairan yang tenang dan tergolong intertidal dengan daerah sekitarnya merupakan tempat pembuangan akhir (TPA) dan pembakaran sampah di Pulau Pramuka.

Daun lamun untuk analisis dibersihkan dari pasir dan kotoran-kotoran yang menempel menggunakan air laut, kemudian dicuci menggunakan air tawar untuk menghilangkan garam-garam yang masih menempel pada daun lamun. Sampel daun lamun yang telah dibersihkan dikeringkan

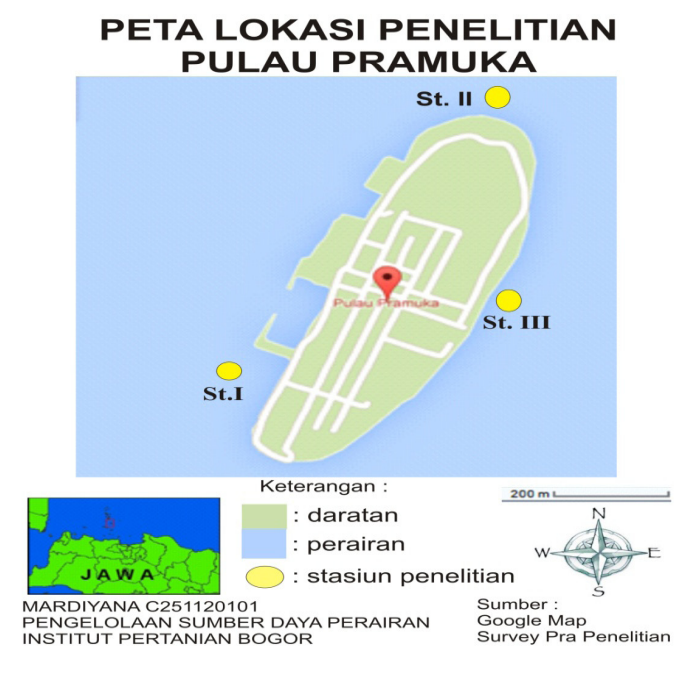

Gambar 1 Lokasi pengambilan sampel. 
dengan sinar matahari sampai kering kemudian dibawa ke laboratorium untuk analisis kandungan senyawa bioaktif dan aktivitas antioksidan, sedangkan sampel daun lamun untuk analisis biomassa epifit langsung diamati dalam keadaan segar.

\section{Pengamatan Biomassa Epifit Lamun}

Pengamatan biomassa epifit pada lamun dilakukan dengan mengambil sampel daun lamun sebanyak 5 helai tiap ulangannya pada tiap stasiun. Lamun yang telah dikumpulkan dikerik epifitnya menggunakan mistar plastik dan dikumpulkan dalam wadah, kemudian luas daun yang dikerik diukur. Epifit yang terkumpul dalam wadah dipindahkan dalam cawan porselin dan dikeringkan pada suhu $105^{\circ} \mathrm{C}$ selama 2 jam. Berat cawan kosong dan yang berisi epifit kering ditimbang, lalu diukur biomassa epifit dengan persamaan:

$$
\text { Biomassa epifit }=\frac{A^{1}-A^{0}}{L}
$$

Keterangan:

$\mathrm{A}^{1}=$ (berat cawan berisi epifit kering).

$\mathrm{A}^{0}=$ (berat cawan kosong).

$\mathrm{L}=$ (luas daun lamun).

\section{Parameter Fisika-Kimia Perairan}

Parameter fisika dan kimia perairan yang diukur adalah suhu, kedalaman, kecerahan dan kecepatan arus perairan yang dilakukan secara insitu.

\section{Ekstraksi Bahan Aktif}

Sebanyak $10 \mathrm{~g}$ bubuk kasar direndam (maserasi) dalam $80 \mathrm{~mL}$ metanol (1:8) selama 48 jam dalam suhu ruang. Sampel hasil ekstraksi disaring dengan kertas saring Whatman nomor 42, pelarut diuapkan dengan vacuum rotary evaporator pada suhu $40^{\circ} \mathrm{C}$. Ekstrak kasar yang diperoleh disimpan dalam lemari pendingin sampai hendak digunakan untuk pengujian antioksidan.

\section{Uji Fitokimia (Harborne 1987)}

Analisis keberadaan komponen metabolit sekunder dalam ekstrak daun lamun dilakukan melalui serangkaian uji fitokimia. Uji fitokimia dilakukan secara kualitatif yang meliputi uji alkaloid, uji steroid/triterpenoid, flavonoid, fenol hidrokuinon, tanin, dan saponin.

\section{Uji Alkaloid}

Sampel sebanyak 0,5 g dilarutkan dalam beberapa tetes asam sulfat $2 \mathrm{~N}$ kemudian diuji dengan tiga pereaksi alkaloid, yaitu pereaksi Dragendorff, pereaksi Meyer, dan pereaksi Wagner. Hasil uji dinyatakan positif bila dengan pereaksi Meyer terbentuk endapan putih kekuningan, endapan coklat dengan pereaksi Wagner dan endapan merah hingga jingga dengan pereaksi Dragendorff.

\section{Uji Flavonoid}

Sampel sebanyak 0,5 g ditambahkan serbuk magnesium $0,1 \mathrm{mg}$ dan $0,4 \mathrm{~mL}$ amil alkohol (campuran asam klorida 37\% dan etanol 95\% dengan volume yang sama) dan $4 \mathrm{~mL}$ alkohol kemudian campuran dikocok. Warna merah, kuning atau jingga yang terbentuk pada lapisan amil alkohol menunjukkan adanya flavonoid.

\section{Uji Fenol Hidrokuinon}

Sampel sebanyak $1 \mathrm{~g}$ diekstrak dengan $20 \mathrm{~mL}$ etanol 70\%. Larutan yang dihasilkan diambil sebanyak 1 mLkemudian ditambahkan 2 tetes larutan $\mathrm{FeCl}_{3} 5 \%$. Terbentuknya warna hijau atau hijau biru menunjukkan adanya senyawa fenol dalam bahan.

\section{Uji Tanin}

Sampel sebanyak 0,5 g ditambahkan $\mathrm{FeCl}_{3}$ kemudian campuran dihomogenkan. Reaksi positif adanya tanin ditunjukkan dengan terbentuknya warna merah pada campuran.

\section{Uji Saponin}

Saponin dapat dideteksi dengan uji busa dalam air panas. Busa yang stabil selama 30 menit dan tidak hilang pada penambahan 1 tetes $\mathrm{HCl} 2 \mathrm{~N}$ menunjukkan adanya saponin. 


\section{Uji Aktivitas Antioksidan dengan Metode DPPH (Aranda et al. 2009)}

Uji aktivitas antioksidan dilakukan berdasarkan kemampuan sampel yang digunakan dalam mereduksi radikal bebas stabil DPPH. Sebanyak 1 mg ekstrak kasar lalu ditambahkan metanol dengan perbandingan 1:1.000. Sebanyak 1,3 mg DPPH diencerkan dengan $25 \mathrm{~mL}$ etanol. Etanol diisikan ke dalam microwell plate yang telah disiapkan sebanyak $1 \mu \mathrm{L}$. Langkah selanjutnya pengisian ekstrak dengan beberapa konsentrasi $(32,5$; 62,$5 ; 125 ; 500 ; 1000 \mathrm{mg} / \mathrm{L}$ ) dan penambahan larutan DPPH. Campuran dihomogenkan dan diinkubasi pada suhu $37^{\circ} \mathrm{C}$ dalam waktu 30 menit. Serapan yang dihasilkan diukur dengan ELISA reader pada panjang gelombang $517 \mathrm{~nm}$. Antioksidan sintetik vitamin C digunakan sebagai kontrol positif.

Persentase penghambatan aktivitas radikal bebas diperoleh dari nilai absorbansi sampel. Persamaan regresi diperoleh dari hubungan antara konsentrasi sampel dan presentase penghambatan aktivitas radikal bebas. Nilai konsentrasi penghambatan aktivitas radikal bebas sebanyak 50\% $\left(\mathrm{IC}_{50}\right)$ dihitung dengan menggunakan persamaan regresi. Nilai $\mathrm{IC}_{50}$ diperoleh dengan memasukkan $\mathrm{y}=50$ serta nilai $\mathrm{A}$ dan $\mathrm{B}$ yang telah diketahui. Nilai $\mathrm{x}$ sebagai $\mathrm{IC}_{50}$ dapat dihitung dengan persamaan:

$$
y=A+B \ln (x)
$$

Keterangan :

$\mathrm{y}=$ persen inhibisi

$\mathrm{x}=$ konsentrasi sampel $(\mathrm{mg} / \mathrm{L})$

$\mathrm{A}=$ slope

$\mathrm{B}=$ intercept

\section{Analisis Data}

Data yang diperoleh dianalisis dengan uji ANOVA untuk menganalisis data kondisi perairan, biomassa epifit, dan aktivitas antioksidan antar stasiun. Jika hasil analisis berbeda nyata dilanjutkan dengan Uji Beda Nyata Terkecil $(B N T p<0,05)$. Analisis data untuk mengetahui hubungan antara biomassa epifit dengan aktivitas antioksidan pada lamun adalah korelasi pearson. Analisis dilakukan dengan bantuan program SPSS 14 .

\section{HASIL DAN PEMBAHASAN}

\section{Biomassa Epifit pada Daun T. hemprichii} serta Kondisi Perairan Pulau Pramuka

Biomassa epifit pada daun lamun yaitu $(14,71-68,66) \mathrm{mg} / \mathrm{cm}^{2}$. Biomassa epifit pada stasiun II dan III menunjukkan perbedaan yang nyata $(p<0,05)$. Rata-rata biomassa epifit terendah adalah $25,93 \mathrm{mg} / \mathrm{cm}^{2}$ pada stasiun II, sedangkan tertinggi adalah $62,94 \mathrm{mg} / \mathrm{cm}^{2}$ pada stasiun III (Tabel 1). Keberadaan epifit secara umum dipengaruhi oleh banyak hal salah satunya adalah kecepatan arus perairan. Stasiun II memiliki kecepatan arus paling tinggi dibandingkan dengan stasiun lainnya,

Tabel 1 Kondisi perairan dan biomassa epifit serta fauna pemangsa lamun T. hemprichii di Pulau Pramuka

\begin{tabular}{lccc}
\hline \multirow{2}{*}{ Parameter } & \multicolumn{3}{c}{ Stasiun } \\
\cline { 2 - 4 } & I & II & III \\
\hline Suhu $\left({ }^{\circ} \mathrm{C}\right)$ & $33,33 \pm 3,21$ & $33,33 \pm 3,06$ & $35,67 \pm 2,89$ \\
Kedalaman $(\mathrm{cm})^{*}$ & $35,33 \pm 13,32^{\mathrm{a}}$ & $50,67 \pm 0,58^{\mathrm{a}}$ & $17,00 \pm 6,93^{\mathrm{b}}$ \\
Kecerahan & dasar & dasar & dasar \\
Kecepatan arus $(\mathrm{m} / \mathrm{s})^{*}$ & $0,04 \pm 0,00^{\mathrm{a}}$ & $0,09 \pm 0,01^{\mathrm{b}}$ & $0,00^{\mathrm{c}}$ \\
Biomassa epifit $\left(\mathrm{mg} / \mathrm{cm}^{2}\right)^{*}$ & $42,76 \pm 16,97^{\mathrm{ab}}$ & $25,93 \pm 9,83^{\mathrm{a}}$ & $62,94 \pm 6,73^{\mathrm{b}}$ \\
Fauna & ++ & +++ & + \\
\hline
\end{tabular}

Keterangan: Simbol huruf superscript yang berbeda menunjukkan perbedaan yang nyata pada taraf uji $5 \%$ (uji beda nyata terkecil); tanda $(+)$ menunjukkan banyaknya fauna (semakin banyak tanda $(+)$ semakin banyak faunanya). 
Tabel 2 Komponen bioaktif ekstrak metanol daun T. hemprichii

\begin{tabular}{lccc}
\hline Komponen Bioaktif & Stasiun I & Stasiun II & Stasiun III \\
\hline Alkaloid & + & + & + \\
Flavonoid & + & + & + \\
Fenol Hidrokuinon & + & + & + \\
Saponin & + & + & + \\
Tanin & - & - & + \\
\hline Keterangan: Tanda $(-)$ & menunjukkan tidak adanya kandungan senyawa fitokimia, \\
& sedangkan tanda $(+)$ menunjukkan adanya kandungan senyawa fitokimia.
\end{tabular}

sehingga epifit memiliki peluang menempel lebih kecil dan biomassanya ditemukan paling sedikit dibandingkan stasiun lainnya. Stasiun III arusnya rendah atau perairannya tenang sehingga epifit akan lebih banyak ditemukan di bagian tumbuhan lamun yang ada di stasiun ini. Jenis epifit yang terlihat menempel pada daun T. hemprichii terdiri dari mikroalga dan telur ikan. Menurut Wenno (2004) lamun yang hidup dalam air tenang memiliki lebih banyak epifit daripada yang hidup dalam air berarus tinggi.

\section{Komponen Bioaktif T. hemprichii}

Komponen bioaktif yang terkandung dalam daun T. hemprichii yaitu alkaloid, flavonoid, fenol hidrokuinon, tanin, dan saponin. Hasil analisis menunjukkan keberadaan komponen bioaktif yang terkandung dalam daun lamun, yaitu alkaloid, flavonoid, fenol hidrokuinon, steroid, tanin, dan saponin (Tabel 2). Senyawa-senyawa yang berpotensi sebagai antioksidan dapat diprediksi dari golongan fenolat, flavonoid dan alkaloid, yang merupakan senyawasenyawa polar (Madhujith dan Shahidi 2005; Nurjanah et al. 2011). Senyawa tanin juga berpotensi sebagai senyawa antioksidan. Menurut Malangngi et al. (2012), kandungan tanin yang semakin banyak maka aktivitas antioksidannya juga semakin besar karena tanin tersusun dari senyawa polifenol yang memiliki aktivitas penangkap radikal bebas.

Tabel 2 menunjukkan bahwa kandungan senyawa bioaktif yang berperan dalam antioksidan ditemukan di seluruh stasiun kecuali senyawa tanin yang hanya terdapat pada lamun yang hidup di perairan stasiun III saja, hal ini diduga dipengaruhi oleh kedalaman perairan stasiun III yang sangat rendah yang menyebabkan suhu perairan yang lebih tinggi mencapai $39^{\circ} \mathrm{C}$ dibanding stasiun lain dan juga lebih terpapar sinar matahari langsung. Hasil penelitian Mossi et al. (2009) menunjukkan adanya korelasi antara kandungan tanin dengan suhu. Perairan yang memiliki suhu tinggi memiliki kandungan tanin yang lebih tinggi pula pada Maytenus ilicifolia.

\section{Hubungan Biomassa Epifit terhadap Aktivitas Antioksidan Thalassia hemprichii}

Nilai $\mathrm{IC}_{50}$ ekstrak daun $T$. hemprichii berkisar antara (563,88-2039,8) $\mathrm{mg} / \mathrm{L}$ (Gambar 2). Molyneux (2004) menyatakan bahwa aktivitas antioksidan ini masih tergolong lemah karena nilai $\mathrm{IC}_{50}$ lebih besar dari200 ppm. Hasil tersebut disebabkan karena ekstrak yang diuji masih berupa ekstrak kasar sehingga perlu dilakukan proses pemurnian. Ekstrak kasar ini diduga mengandung senyawa aktif lain yang tidak memiliki aktivitas antioksidan (Nurjanah et al. 2011). Adanya epifit pada daun lamun sebenarnya memberikan suatu tekanan stres biologi yang dapat merangsang lamun untuk memproduksi senyawa kimia perlindungan diri. Senyawa ini yang berperan dalam aktivitas antioksidan. Atmoko dan Ma'ruf (2009) melaporkan bahwa senyawa kimia yang bermanfaat dari tumbuhan adalah hasil dari metabolit sekunder misalnya fenolik yang berfungsi 


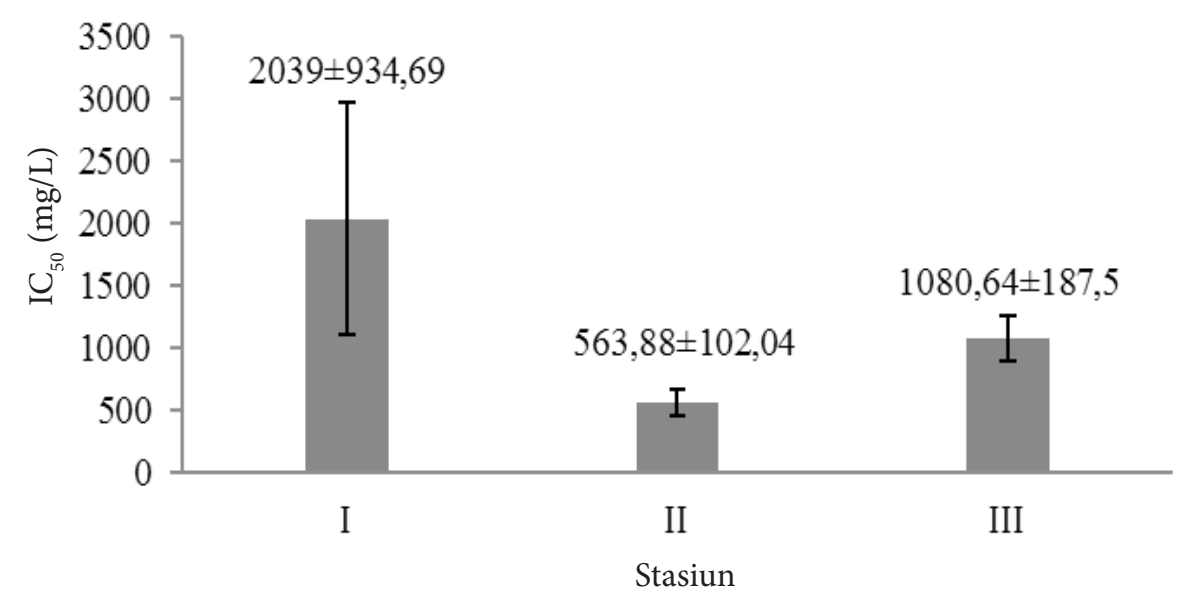

Gambar 2 Aktivitas antioksidan $\left(\mathrm{IC}_{50}\right)$ dari ekstrak metanol daun lamun T. hemprichii yang hidup di perairan Pulau Pramuka (Huruf yang berbeda menunjukkan perbedaan yang nyata pada $\mathrm{p}<0,05)$.

sebagai pelindung terhadap serangan atau gangguan yang ada di lingkungan, sebagai antibiotik, dan juga sebagai antioksidan. Sureda et al. (2008) melaporkan organisme epifit dapat menyebabkan kerusakan pada daun lamun tersebut sebagai hasil dari stres oksidatif dan kerusakan sel. Hasil analisis korelasi Pearson menunjukkan bahwa antara biomassa epifit dengan aktivitas antioksidan $\left(\mathrm{IC}_{50}\right)$ pada daun T. hemprichii memiliki nilai $\mathrm{r}=0,99$. Hubungan positif ini menunjukkan bahwa semakin tinggi biomassa epifit maka nilai $\mathrm{IC}_{50}$ akan semakin tinggi sebagai akibat adanya lapisan epifit pada daun lamun. Lapisan epifit dapat melindungi daun lamun dari paparan sinar UV matahari, tetapi epifit dengan biomassa terlalu tinggi juga dapat menghalangi sinar matahari sehingga dapat mengganggu proses fotosintesis. Proses fotosintesis menghasilkan senyawa yang berperan untuk pertumbuhan dan senyawa lain yang tidak berperan dalam pertumbuhan atau yang dikenal dengan metabolit sekunder (Aho dan Beck 2011).

\section{KESIMPULAN}

Aktivitas antioksidan tertinggi terdapat pada stasiun II dengan IC $_{50} 563,88-2.039,8$ $\mathrm{mg} / \mathrm{L}$ yang berpotensi untuk dijadikan sumber antioksidan alami baru. Biomassa epifit sangat berpengaruh terhadap produksi senyawa kimia yang berperan dalam aktivitas antioksidan.

\section{DAFTAR PUSTAKA}

Aho K, Beck E. 2011. Effects of ephiphyte cover on seagrass growth rate in two tidal zones. Darthmouth Undergraduate Journal of Sciences 8(3):43-44.

Aranda RS, Lopez LAP, Arroyo JL, Garza BAA, Torres NW. 2009. Antimicrobial and antioxidant activities of plants from northeast of Mexico. Evidence-Based Complementary and Alternative Medicine 20(11): 1-6.

Atmoko T, Ma'ruf A. 2009. Uji toksisitas dan skrining fitokimia ekstrak tumbuhan sumber pakan orang utan terhadap larva Artemia salina L. Jurnal Penelitian dan Konservasi Alam 6(1): 37-45.

Choi HG, Lee JH, Park HH, Sayegh FAQ. 2009. Antioxidant and antimicrobial activity of Zostera marina L. extract. Algae 24(3): 179-184.

Hanani E, Mun'im A, Sekarini R. 2005. Identifikasi senyawa antioksidan dalam Spons Callyspongia sp. dari Kepulauan Seribu. Majalah Ilmu Kefarmasian 2(3): 127-133.

Harborne JB. 1987. Phytochemical methods. Ed. ke-2. New York: Chapman \& Hall. 
Madhujith T, Shahidi F. 2005. Antioxidant potential of Pea Beans (Phaseolus vulgaris L.). Journal of Food Science 70(1):85-90.

Malangngi LP, Sangi MS, Paendong JJE. 2012. Penentuan kandungan tanin dan uji aktivitas antioksidan ekstrak biji buah alpukat (Persea americana Mill.). Journal MIPA Universitas Sam Ratulangi 1(1): 5-10.

Manivannan K, Anantharaman P, Balasubramanian T. 2012. Evaluation of antioxidant properties of marine microalga Chlorella marina (Butcher 1952). Asian Pacific Journal of Tropical Biomedicine 5(3):342-S346.

Marhaeni B, Radjasa OK, Bengen DG, Kaswadji RF. 2010. Screening of bacterial symbionts of seagrass Enhalus sp. against biofilm-forming bacteria. Journal of Coastal Development 13(2):126-132.

Molyneux P. 2004. The use of the stable free radical diphenylpicryl-hydrazyl (DPPH) for estimating antioxidant activity. Songklanakarin Journal of Science and Technology 26:211-219.

Mossi AJ, Mazutti M, Paroul N, Corazza ML, Dariva C, Cansian RL, Oliveira JV. 2009. Chemical variation of tannins and triterpenesin Brazilian populations of Maytenus ilicifolia Mart Ex Reiss. Brazilian Journal Biology 69(2): 339-345.

Murniasih T. 2003. Metabolit sekuder dari spons sebagai bahan obat-obatan. Oseana 28(3): 27-33.

Nurjanah, Izzati L, Abdullah A. 2011. Aktivitas antioksidan dan komponen bioaktif kerang pisau (Solen spp.). Jurnal Ilmu Kelautan 16(3): 119-124.

Regalado EL, Menendez R, Valdes O, Morales RA, Laguna A, Thomas OP, Hernandez Y, Noguieiras C, Kijjoa A. 2012. Phytochemical analysis and antioxidant capacity of BM-21, a bioactive extract rich in polyphenolic metabolites from the seagrass Thalassia testudinum. Natural Product Communications 7(1): 47-50.

Rohmatussholihat. 2009. Antioksidan, penyelamat sel-sel tubuh manusia. BioTrends 4(1):5-9.

Sen S, Chakraborty R, Sridhar C, Reddy YSR, De B. 2010. Free radicals, antioxidants, diseases and phytomedicines: current status and future prospect. International Journal of Pharmaceutical Sciences Review and Research 3(1):91-100.

Sureda A, Box A, Terrados J, Deudero S, Pons A, 2008. Antioxidant response of the seagrass Posidonia oceanica when epiphytized by the invasive macroalgae Lophocladia lallemandii. Marine Environment Resources 66(3):1-24.

Tangke U. 2010. Ekosistem padang lamun (manfaat, fungsi, dan rehabilitasi). Jurnal Ilmiah Agribisnis dan Perikanan 3(1): 9-29

Wenno PA. 2004. Kolonisasi epifit pada daun lamun Thalassia hemprichii dan Enhalus acoroides. Ichthyos 3(1):21-26.

Yoon NY, Lee SH, Wijesekara I, Kim SK. 2011. In vitro and intracellular antioxidant activities of brown alga Eisenia bicyclis. Fish Aquatic Science 14(3):179-185. 